\title{
Mechanical properties of a high amylose content corn starch based film, gelatinized at low temperature
}

Propriedades mecânicas de filme a base de amido de milho de alto teor de amilose gelatinizado em baixa temperatura

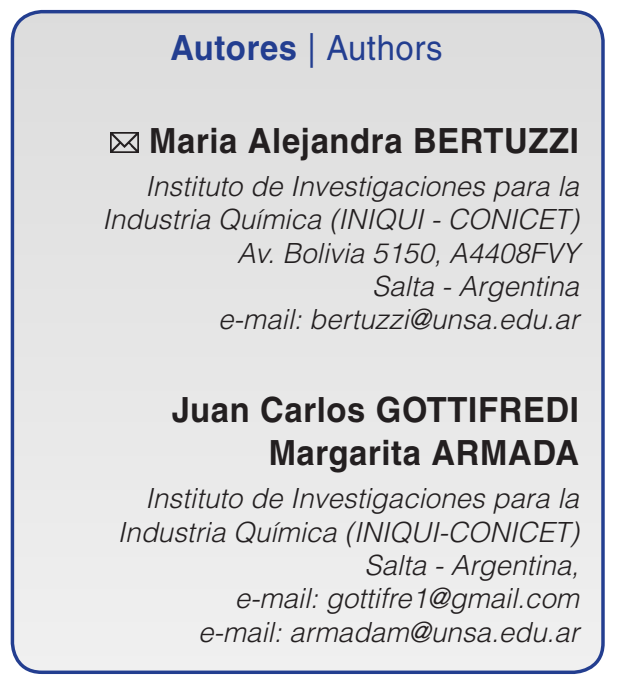

Autor Correspondente / Corresponding Author

Recebido / Received: 25/07/2011 Aprovado / Approved: 04/06/2012 Publicado / Published: set./2012

\section{Summary}

In the present study, a better knowledge of the influence of plasticizer content, storage relative humidity and film thickness on the mechanical properties of high amylose corn starch based films gelatinized at low temperature, is presented. The mechanical properties, tensile strength and percentage of elongation at break of high amylose corn starch films plasticized with glycerol were evaluated using tension tests. The films exhibited an increase in elongation and a decrease in tensile strength with increasing plasticizer concentration. When the glycerol level was high, some fissures were detected in the dry films, possible due to phase separation (starch-glycerol) phenomena. Film crystallinity is related to the reorganization capacity of the polymer chain, and thus the relative film crystallinity should increase with plasticizer content (glycerol and water). The mechanical properties were found to be strongly dependent on the water content due to the hydrophilic nature of starch films. The influence of moisture sorption on tensile strength was similar to that of plasticization with glycerol. The relationship between polymer chain mobility and water content explained this behavior. Elongation suffered a different effect and maximum values were reached at $45 \%$ relative humidity. The final drop in elongation was due to a softening of the structure at high relative humidity. The thicker the film the longer the drying time required, leading to greater relative crystallinity due to the corresponding increase in the possibility for chain reorganization. As a consequence, linear increases in tensile strength and elongation were observed with film thickness over the whole range studied (30 to $100 \mu \mathrm{m}$ ).

Key words: Starch films; Mechanical properties; Tensile strength; Elongation at break; Crystallinity. 


\section{Resumo}

No presente estudo, é apresentado um melhor conhecimento da influência do teor em plastificante, da umidade relativa de armazenamento e da espessura do filme nas propriedades mecânicas do filme baseado em amido de milho de alto conteúdo de amilose, gelatinizado em baixa temperatura. As propriedades mecânicas, a resistência à tração e a porcentagem de alongamento na ruptura dos filmes de amido de milho de alta amilose plastificados com glicerol foram avaliadas utilizando-se testes da tensão. Os filmes apresentaram aumento do alongamento na ruptura e diminuição da resistência à tração com a concentração crescente de plastificante. Quando o nível de glicerol foi elevado, algumas fissuras nos filmes secos foram detectadas, possivelmente em razão dos fenômenos de separação de fases (amido-glicerol). A cristalinidade do filme está relacionada à capacidade de reorganização da cadeia polimérica; assim, a cristalinidade relativa do filme deve aumentar com o conteúdo de plastificantes (glicerol e água). As propriedades mecânicas mostraram-se fortemente dependentes do teor de água, por causa da natureza hidrofílica dos filmes de amido. A influência da umidade de sorção na resistência à tração foi semelhante à plastificação com glicerol. A relação entre a mobilidade da cadeia polimérica e o teor em água explica esse comportamento. $\mathrm{O}$ alongamento sofreu um efeito diferente: valores máximos foram atingidos em $45 \%$ da umidade relativa. A queda final em alongamento deveu-se ao amolecimento da estrutura em umidade relativa alta. Os filmes mais espessos requerem mais tempo de secagem; dessa forma, a cristalinidade relativa é maior porque se aumenta a possibilidade de reorganização das cadeias. Como consequência, foi observado um aumento linear da resistência à tração e do alongamento na ruptura em relação à espessura do filme, sobre toda a faixa estudada (30 a $100 \mu \mathrm{m})$.

Palavras-chave: Filmes de amido; Propriedades mecânicas; Resistência à tração; Alongamento na ruptura; Cristalinidade. 


\section{Introduction}

There is an increasing interest in using renewable resources as food packaging. Polysaccharides such as starches, cellulose derivatives and plant gums are being studied as edible films and coatings for food packaging and preservation, and since 1950 many studies have been reported on starch based films cast from solutions or gels (LIU and HAN, 2005; LOURDIN et al., 1997; ZHANG and HAN, 2006). High amylose corn starch is known to produce strong, flexible films probably due to amylose crystallization (MYLLÄRINEN et al., 2002; VAN SOEST et al., 1996). In general, films based on amylose or high amylose corn starch (HACS) were obtained from solutions prepared at very high temperatures (120-155 ${ }^{\circ} \mathrm{C}$ ) (BADER and GÖRITZ, 1994; LIU and HAN, 2005; RINDLAV-WESTLING et al., 1998). The treatment of HACS with alkali favors starch dissolution and the expansion of the amylose coil due to charge repulsion (CHEN and JANE, 1994), which facilitates film formation. Liu and Han (2005) studied the starch film formation process from solutions and found that the formation of films from dilute starch solutions followed three steps, helical formation (caused by cooling), aggregation or jelation, and finally reorganization of the aggregates, the last two steps occurring during dehydration. The starch helices packed in regular arrays determine the film crystallinity, the degree of which can be evaluated by X-ray diffraction. Bader and Goritz (1994) and Rindlav-Westling et al. (1997) showed that the degree of crystallinity of starch films depended on the temperature, air humidity and the drying time elapsed from gel to film.

The mechanical properties of edible films are important to preserve their barrier behavior. Adequate mechanical strength ensures the integrity of a film and its resistance to breakage and abrasion and reduces the occurrence of defects, such as pinholes or fissures, which ruin the barrier properties. Adequate flexibility guarantees sufficient plasticity to adapt to possible deformation without breaking during filling (GUILBERT et al., 1995).

The mechanical properties of edible films and coatings depend on the type of film forming material and especially on its structural cohesion. The insertion of plasticizer molecules in the polymer matrix modifies the organization and energy involved in the threedimensional structure of film-forming polymers. The addition of a plasticizer reduces the mechanical strength of edible films but increases their elongation (RYU et al., 2002). The plasticizer must be compatible with the film forming polymer to ensure its homogeneous distribution in the three dimensional structure of the film, and its selection may affect the mechanical properties of the edible films. Some monosaccharides and polyols have been characterized as plasticizers of starch based films (ZHANG and HAN, 2006). Glycerol has often been used in edible films to change their physical properties, and Jangchud and Chinnan (1999) found that amongst several plasticizers studied, glycerol was the best one for water-soluble polymers. Rindlav-Westling et al. (1998) found that the mechanical strength of glycerol-plasticized films was dependent on the relative crystallinity for amylopectin films and on the network microstructure for amylose films. They showed that the relative crystallinity of glycerol-plasticized amylopectin films increased with increasing air humidity during film formation, whereas non-plasticized amylopectin films remained amorphous independent of the air humidity during drying. The addition of glycerol facilitated mobility of the chains, and higher air humidity during film formation lead to a longer crystallizing time during the drying process. However, no information is available in the current literature concerning high amylose corn starch based films obtained using a low temperature procedure with an alkaline pretreatment of the starch.

Water is the most common plasticizer and it is very difficult to regulate water sorption in hydrophilic films. The interaction of water with polymers must be considered to explain the modifications induced in the physical properties by the presence of sorbed moisture. The sorption of water vapor by dried materials is generally assumed to involve water molecules bound to specific hydrophilic sites, such as carboxylic, amino and hydroxyl residues, at lower water activities $\left(a_{w}\right)$. Chang et al. (2000) observed that water played a dual role as a plasticizer and an anti-plasticizer, depending on the physical property measured. They found an anti-plasticizing effect of water on the tensile strength and toughness at a moisture content ranging from 4 to $8 \%\left(a_{w}<0.4\right)$. At higher $a_{w}$, multilayer adsorption was accompanied by swelling and conformational changes in the macromolecular structure (CUQ et al., 1997).

Few contributions have been presented dealing with the influence of film thickness on edible films properties but some authors have demonstrated that film thickness can affect the water vapor barrier and tensile properties of edible films (CUQ et al., 1996; LONGARES et al., 2004; SOBRAL, 2000)

The purpose of the present contribution was to gain a better understanding of the relationship between the mechanical properties of high amylose corn starch films obtained by a low temperature method with an alkaline pretreatment of the starch, and the plasticizer concentration, water activity and film thickness.

\section{Materials and methods}

\subsection{Film preparation and casting}

High amylose corn starch with an amylose content of about $70 \%$ and native lipid content of $1.2 \%$ was used. The film forming dispersion consisted of $1 \mathrm{~g}$ of starch, 
$10 \mathrm{~mL} 0.25 \mathrm{~N}$ sodium hydroxide and $10 \mathrm{~mL}$ distilled water and it was mixed with magnetic stirring for $60 \mathrm{~min}$. The dispersion was then gelatinized in a shaking water bath at $78-80^{\circ} \mathrm{C}$ for $10 \mathrm{~min}$. This procedure ensured disintegration of the starch granules to form a homogeneous solution and glycerol (Merck, Whitehouse Station, N.J., U.S.A.) was added as the plasticizer. While still hot, the starch solution was cast over plastic dishes and the dishes placed in an air-circulating oven at $35^{\circ} \mathrm{C}$ until the films were dry. After $15 \mathrm{~h}$, the dishes were removed from the oven and the films peeled off. Isotropic films were obtained with excellent transparency. Films with various thicknesses were prepared by pouring different amounts of starch solution onto the dishes.

\subsection{Measurement of film thickness}

The thickness of the film specimens was measured with an electronic micrometer $(0.001 \mathrm{~mm}$ accuracy, Fowler, Cole-Parmer Instrument Co.), the thickness reported being the mean value of five measurements, which was used as the specimen thickness in the calculations. SEM observations of the film cross-section also allowed for an evaluation of film thickness, and were used to verify the micrometer measurements.

\subsection{X-ray diffraction}

X-ray diffraction spectra were obtained using a Rigaku Denki D-Max IIC diffractometer with Cu K $\alpha$ radiation $(\lambda=0.1542 \mathrm{~nm}), 40 \mathrm{KV}$ and $20 \mathrm{~mA}$ over an angular range of $3-40^{\circ}$ with a step size of 0.02 . The samples were previously conditioned at 50\% $\mathrm{RH}$ and $25^{\circ} \mathrm{C}$. The area of the crystalline peak diffraction relative to the total area of the diffractogram was taken as a measure of the relative crystallinity.

\subsection{Scanning electron microscopy (SEM)}

Cross-sections and surfaces of HACS films were examined by SEM using a JEOL JSM 6480 LV scanning microscope. For cross-sectional observations, the films were cryo-fractured by immersion in liquid nitrogen and stored at $25{ }^{\circ} \mathrm{C}$ over silica gel. The film samples were mounted on bronze stubs, coated with a gold-palladium alloy and observed using an accelerating voltage of $15 \mathrm{kV}$.

\subsection{Mechanical properties}

The tensile properties were measured using a QTS Twenty Five texturometer (CNS Farnell, England) according to ASTM D882 "Standard test methods for tensile properties of thin plastic sheeting" (ASTM, 2010) with some modifications. The films were cut into $25.4 \mathrm{~mm}$ wide and $80.0 \mathrm{~mm}$ long strips using a sharp scalpel. The ends of the strips were mounted between cardboard grips using double-side adhesive tape such that the final film area exposed was $25.4 \mathrm{~mm} \times 50.0 \mathrm{~mm}$. The texturometer was set to the tensile mode, the initial grip separation was $50 \mathrm{~mm}$, and force and elongation were recorded during extension at $20 \mathrm{~mm} \cdot \mathrm{min}^{-1}$ up to break. To evaluate how the glycerol concentration and thickness affected the mechanical properties, all the film strips were equilibrated for a week in a cabinet conditioned at $25^{\circ} \mathrm{C}$ and $52 \%$ relative humidity using saturated magnesium nitrate solution. Also, the tensile strength (TS) and percentage of elongation at break (\%E) of the films were evaluated after storage at different values of relative humidity for a week. Different constant relative humidity environments were obtained using different saturated salt solutions ( $\mathrm{LiCl}$, $\mathrm{CH}_{3} \mathrm{COOK}, \mathrm{MgCl}_{2}, \mathrm{~K}_{2} \mathrm{CO}_{3}, \mathrm{Mg}\left(\mathrm{NO}_{3}\right)_{2}, \mathrm{NaBr}, \mathrm{NaCl}$ and $\mathrm{KCl}$ ). Three film samples were stored in desiccators containing the salt solutions at $25^{\circ} \mathrm{C}$ prior to the tension assay. Each film sample was cut into three strips and each strip was tested, such that nine measurements were taken for each kind of film sample.

\section{Results and discussion}

\subsection{Plasticizer}

Figure 1 shows some representative stressstrain curves obtained for high amylose corn starch films plasticized with different glycerol concentrations (g glycerol/g high amylose corn starch). These curves are typical of any viscoelastic material. At the beginning, the stress increased rapidly and was proportional to the strain; that is, the elastic reversible strain area (elastic deformation). When the yield point was reached, plastic flow started and the strain was no longer reversible. This part is called the plastic strain area. During the period of plastic flow, the curve continuously bendt away from the stress coordinate, indicating an increase in the rate of flow as stress was applied. Plastic flow continued until the film ruptured.

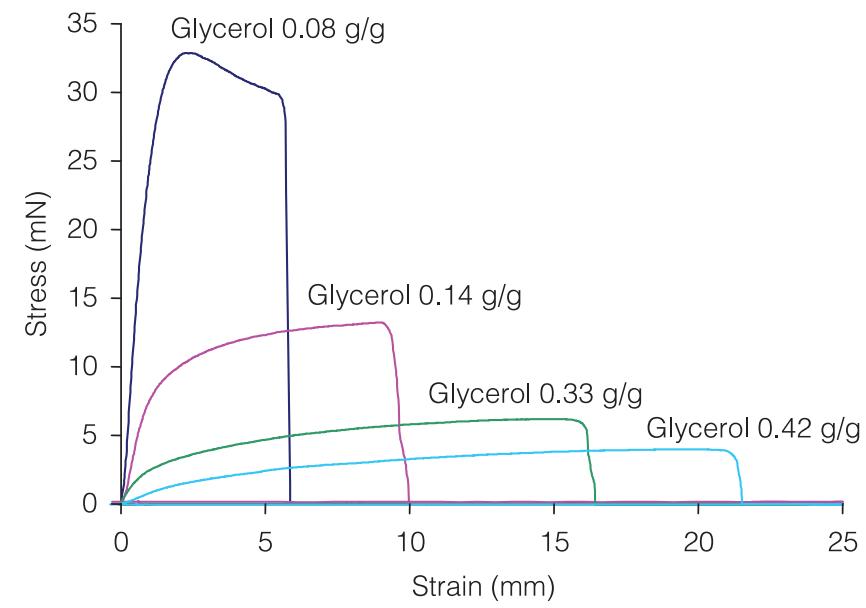

Figure 1. Stress strain curves for high amylose corn starch films obtained with different plasticizer contents (as indicated). 
The curve with $8 \%$ glycerol content exhibited relatively high TS and low \%E. The high TS values observed in these films can be attributed to the numerous hydrogen bonds between the starch chains. These bonds contribute to cohesiveness and low flexibility. When glycerol was incorporated in the starch network, competition for hydrogen bonding occurred. As a result, direct interactions between the starch chains were partly reduced due to hydrogen bond formation with glycerol, allowing the polymer chains more freedom of motion. When the glycerol content was increased, a decrease in rigidity of the film (slope of the elastic zone), an increase in pliability and a change in the character of plastic flow were observed. The relatively long region of plastic flow is proof that the film possesses considerable inherent plasticity. The starch films became more flexible as the plasticizer concentration was increased, due to greater possibilities for chain displacement. In fact, as shown in Figure 2, the \%E increased proportionally to the plasticizer content in the range studied, whereas TS showed a substantial decrease, in agreement with previous studies (MYLLÄRINEN et al., 2002; RYU et al., 2002; ARAUJOFARRO et al., 2010; KOCH et al., 2010). Myllärinen et al. (2002) and Zhang and Han (2006) obtained high amylose corn starch films using the traditional method under high pressure and temperature conditions. They TS values obtained were higher and the \%E lower than those observed in Figure 2. This could be explained by the fact that in an alkaline medium starch molecules exhibit an extended configuration that favors the formation of extensive interactions between the chains, enhancing some mechanical properties, such as elongation.

The plasticizing effect of glycerol was also observed in other edible films such as gluten films (MANGAVEL et al., 2002), soy protein films (CUNNINGHAM et al., 2000) and other animal proteins (PASCHOALICK et al., 2003).

Some studies suggested that phase separation occurred in film-forming starch solutions at room

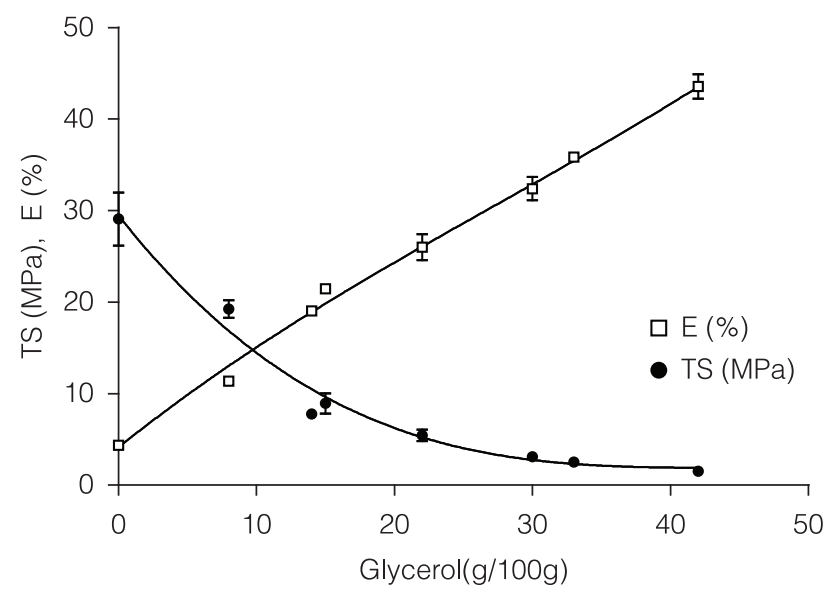

Figure 2. Tensile strength and elongation of starch based films as a function of glycerol content. temperature, since crystallization of the amylose occurred faster than reorganization and crystallization of the amylopectin. However, the two phases were integrated seamlessly by intermolecular interactions between the amylose and amylopectin (LIU and HAN, 2005). Figure 3a shows the cross section of a high amylose corn starch film with no plasticizer. The films showed smooth surfaces and no pores or cracks were detected by a SEM analysis of the non-plasticized and low glycerol content films. Cereda et al. (2000) found similar surfaces in cassava starch films.

Studies with dielectric methods, dynamic mechanical and calorimetric techniques indicated that although glycerol was an effective plasticizer of amylose, amylose-glycerol mixtures were only partially miscible (MOATES et al., 2001; LÓPEZ et al., 2011). This could explain why films elaborated with high glycerol levels (45\% w/w of starch) present fissures in their structure, as shown in Figure 3b.

Figure 4 shows X-ray diffractograms of high amylose corn starch films prepared with and without glycerol. The plasticizer seems to facilitate crystal growth and recrystallization due to higher mobility of the polymeric chains and greater possibilities for polymer chain alignments during the film drying process and storage. This is in agreement with the results reported by Rindlav-Westing et al. (1998) and by Van Soest and Vliegenthart (1997). Rindlav-Westing et al. (1998) found an increase in amylopectin crystallization in glycerolplasticized films in relation to non-plasticized films. According to their results, this higher relative crystallinity depended on the relative humidity during film formation.

\subsection{Relative humidity}

The starch-plasticizer-water systems studied were more sensitive to environmental humidity when the plasticizer content was high, possibly due to the origin of the hydrogen bonds between the plasticizer and water. The glycerol concentration was kept at 30\% of the starch weight to determine the effect of environmental relative humidity on the mechanical properties of the starch films.

The experimental data for moisture sorption at $30{ }^{\circ} \mathrm{C}$ for high amylose corn starch films plasticized with 20,40 and $60 \%$ glycerol as a function of water activity, were reported in a previous paper (BERTUZZI et al., 2007). The sorption curves of high amylose corn starch films are typical of water vapor sensitive polymers, and present a relatively little inclined slope at low values of water activity $\left(\mathrm{a}_{\mathrm{w}}\right)$, but take an exponential course at high relative humidity (above 0.60). The structure of the film is appreciably modified at $a_{w}$ values above 0.60. Under these conditions, polymeric chains swell, altering their structure. Thus the water plasticization of starch based films had an 

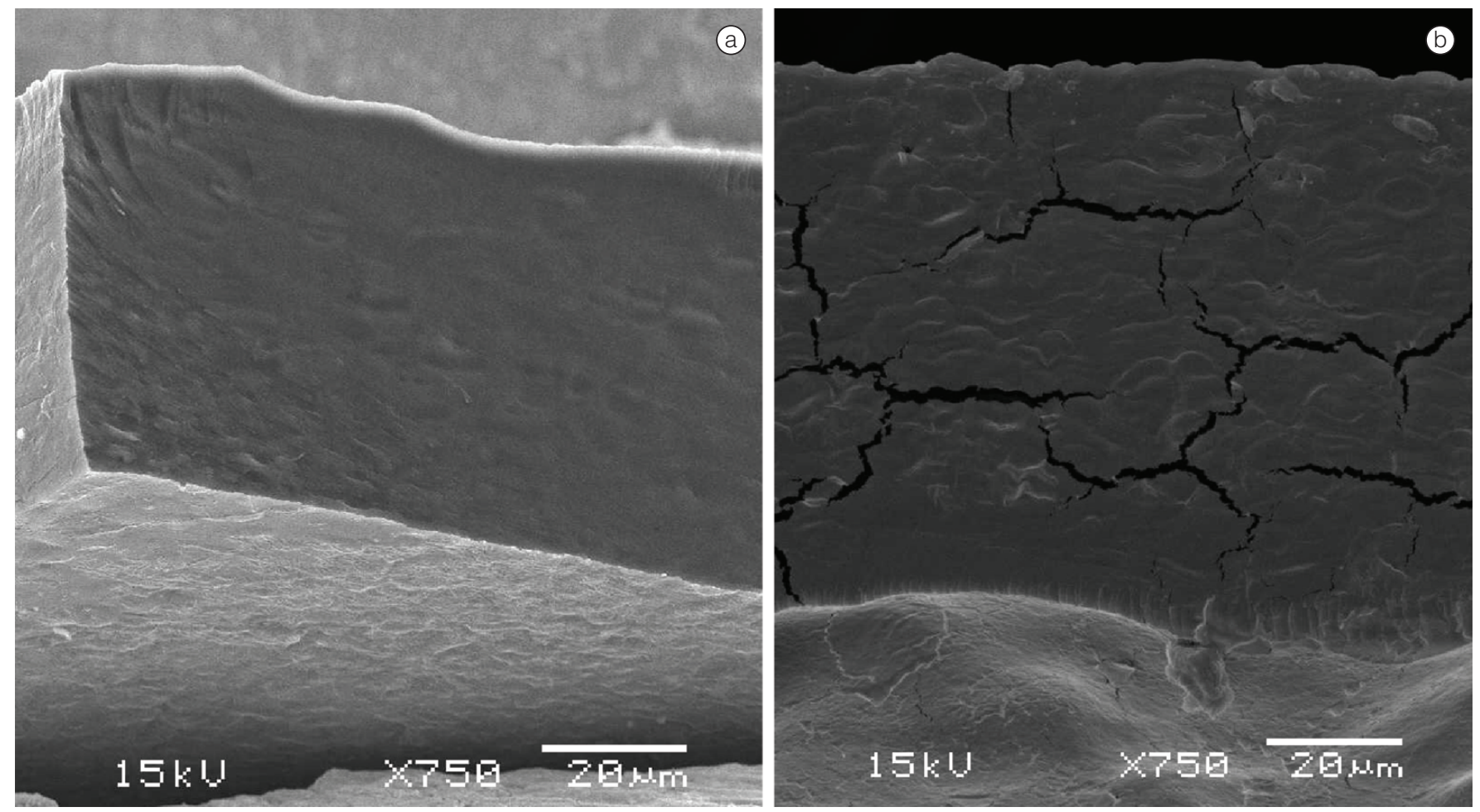

Figure 3. Cross-section micrographs of HACS films with no plasticizer (a) and elaborated with $45 \%$ glycerol (b). SEM magnification is indicated in the micrographs.

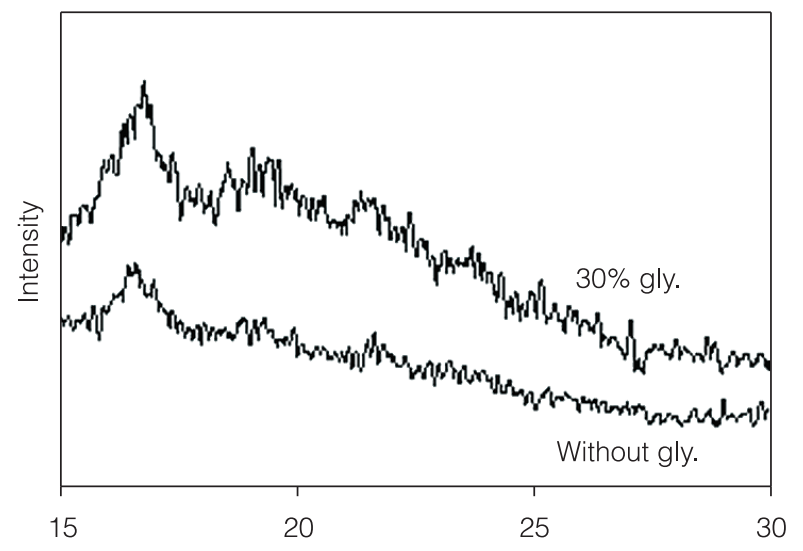

$2 \theta$

Figure 4. X-ray diffraction patterns of HACS films with $30 \%$ glycerol (top) and without plasticizer (bottom).

important effect on their mechanical properties. At low $a_{w}$ (0.11), force steadily increased until the sample ruptured.

These films showed very little deformation at rupture, which is characteristic of a brittle fracture. At this water activity value, the water content of the film was below $2 \%$ according to the sorption isotherm (BERTUZZI et al., 2007). With further hydration $\left(a_{w}>0.11\right)$, non linear force-deformation curves described the viscoelastic behavior of the starch based films. Figure 5 shows the effects of variations in the $a_{w}$ on the tensile strength and elongation. These results can be attributed to plasticization of the hygroscopic polymer matrix by water, in agreement with previous publications (CHANG et al., 2000, LAZARIDOU and BILIADERIS, 2002, PAES et al., 2008). During hydration, the water sorbed onto the dry starch based films induced a classical plasticizing effect on the functional properties of the film. An increase in relative humidity induced an exponential decrease in tensile strength throughout the water activity range studied. At low relative humidity, the elongation increased markedly as the water activity increased. Further hydration caused a drop in elongation. As stated above, when the $a_{w}>0.60$, the water content of the film increased exponentially since the water molecules interacted with the starch chains. Water-polymer interactions developed to the detriment of polymer-polymer bonds, reducing the density of intermolecular interactions. Thus the starch chains became more mobile and the network lost its cohesiveness and elasticity (Figure 5). Chang et al. (2000) observed similar behavior for starch films.

\subsection{Film thickness}

High amylose corn starch based films prepared with $30 \%$ glycerol as plasticizer and conditioned at 52\% $\mathrm{RH}$ were tested. Experimental TS and E\% data as a function of film thickness are presented in Figure 6. As the TS increased, so the thickness also increased over the range studied (30 to $100 \mu \mathrm{m}$ ). Ideally the TS should be constant as the film thickness varies, since the material structure is considered homogeneous regardless of the amount of 
suspension used to form the film. However, to the contrary, the observations showed an important dependence of TS on film thickness. This phenomenon can be explained in terms of the polymer matrix formation during the drying step of the suspension. In the first step, a gel was formed as the water evaporated, and the first film formed at the interface shrank due to further evaporation of water. By observing the evaporation surface of the films (top surface in Figure 3a, and bottom surface in Figure 3b) a thin, more homogeneous and dense zone can be seen.

During the first step the water evaporated quickly and the rate was mainly controlled by the external mass transfer coefficient. Since the first film structure was formed above the suspension, the drying rate was mainly controlled by diffusional phenomena through the film structure formed on the evaporation surface. The rate of evaporation became very slow and the time needed to complete the process increased as did the film thickness. As the time of the film formation process increased, so a better molecular arrangement in the polymer structure is to be expected. Under these circumstances the degree of crystallinity of the polymer must also increase.

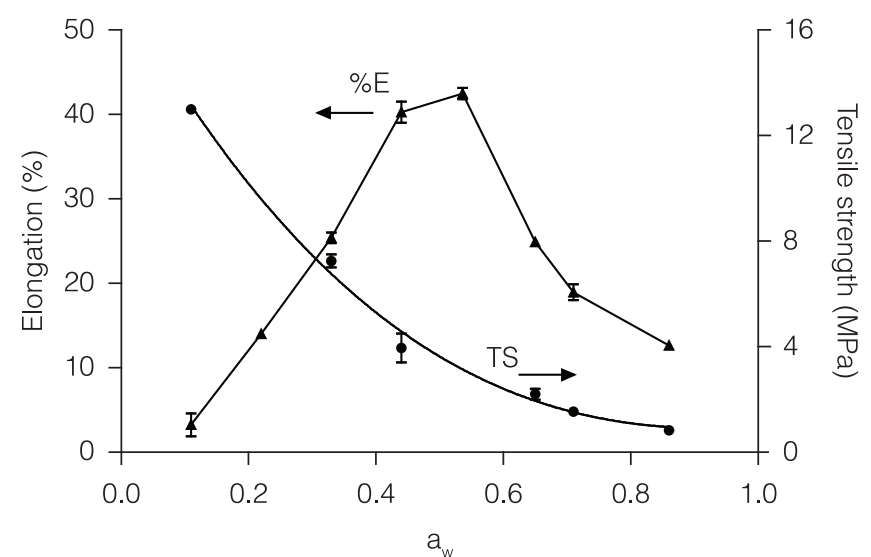

Figure 5. Tensile strength and elongation of starch based films as a function of water activity.

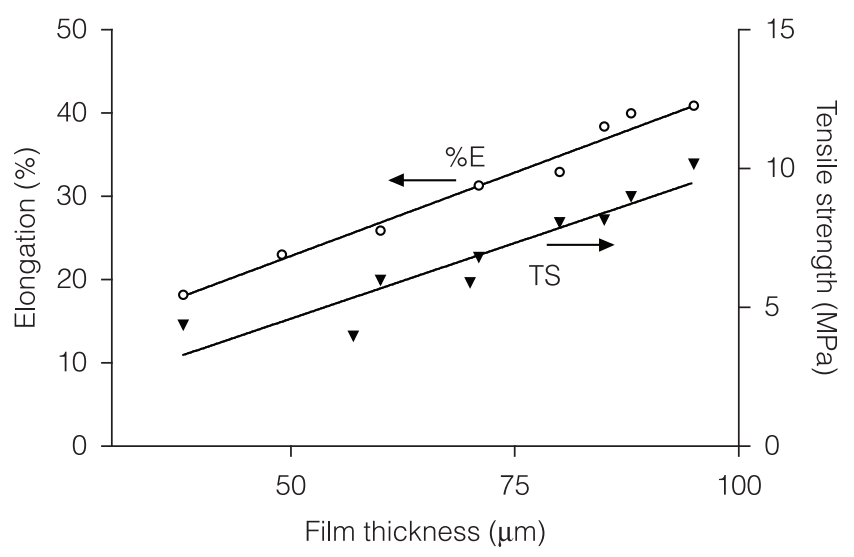

Figure 6. Tensile strength and elongation of starch based films as a function of film thickness.
In a previous paper (BERTUZZI et al., 2007), a detailed description of the crystallographic patterns of high amylose corn starch based films was presented. It was shown that the degree of crystallinity of the films depended on the ability of the chain to form crystals as well as on the mobility of the chains during the crystallization process. As a consequence, the thicker films required a longer drying time, and thus an increase in crystallinity with film thickness is to be expected. In Figure 7 an increase in peak intensity with film thickness can be clearly observed. This effect was more noticeable when observing the peak of $2 \theta=17^{\circ}(d=5.2 \AA)$.

When the resulting film was thin, the evaporation process was fast and the water molecules left the suspension quickly, and hence the shrinking and deformation processes were quite random. The resulting polymer structure was mainly amorphous and the mechanical properties corresponded to a rather rubbery material with little resistance to elongation stress. Bader and Goritz (1994) and Rindlav-Westling et al. (1997) showed that the degree of crystallinity of starch films depended on the temperature, air humidity and the time required to dry the film. This was in agreement with the present results, since a thicker film required a longer drying time.

The increase in degree of crystallinity of the polymer matrix was directly related to high TS values (VAN SOEST et al. 1996; FLORES et al., 2007). As shown in the X-ray diffractogram (Figure 7), an increase in film thickness led to high relative crystallinity, indicating a direct relationship between TS and film thickness (Figure 6). Park et al. (1993) and Sobral (2000) also reported that the TS of edible films increased with thickness. On the other hand Cuq et al. (1996) showed that for thicker myofibrillar protein based films $(>30 \mu \mathrm{m})$ the tensile strength was independent of film thickness. However for thinner films $(<30 \mu \mathrm{m})$, they found dependence on film thickness.

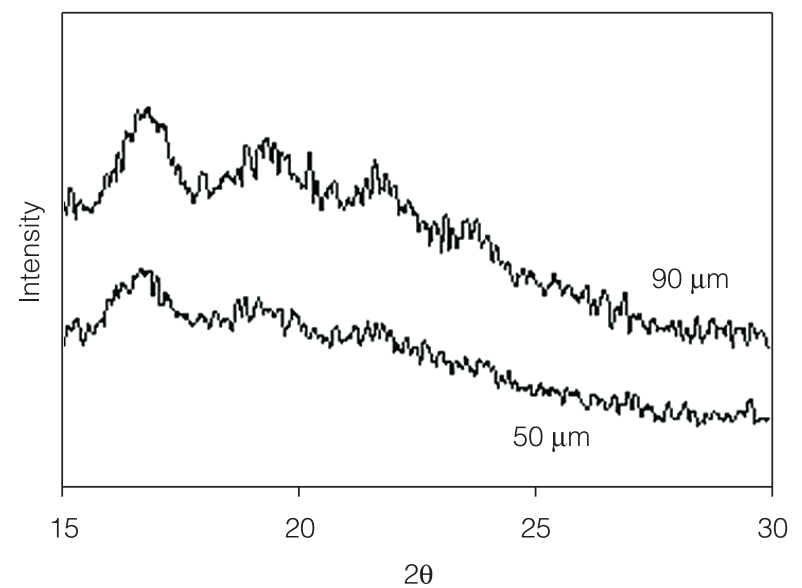

Figure 7. X-ray diffraction patterns of HACS films with $90 \mu \mathrm{m}$ (top) and $50 \mu \mathrm{m}$ (bottom) of film thickness. 
Mechanical properties of a high amylose content corn starch based film, gelatinized at low temperature BERTUZZI, M. A. et al.

Figure 6 shows that the elongation at break of starch based films increased linearly with film thickness over the range studied. A more stretchable matrix was formed in thicker films, probably because these films had a better organization of the starch chains and a greater cross sectional area, permitting greater extension under stress than the thinner films. Thus, thinner films reached a limit in their ability to stretch quicker than thicker films. Jansson and Thuvander (2004) found that starch film strength and strain showed a strong dependence on film thickness. Longares et al. (2004) and Park et al. (1993) reported that the elongation of cellulose derivatives and of whey protein isolate films increased with increase in thickness. In contrast, Cuq et al. (1996) and Sobral (2000), using a puncture test, found no correlation between elongation and film thickness.

\section{Conclusions}

Glycerol produced plasticization of starch films, giving a more plastic like structure. By increasing chain mobility in the starch network, a decrease in TS and an increase in E\% were clearly noticed. For any starch film, the optimal mechanical properties could be achieved at a given glycerol content. In the present experiments, appropriate mechanical behavior was found in a range from 15 to $30 \%$ (w/w) glycerol. A greater glycerol concentration led to phase separation due to partial miscibility between the starch and glycerol. As a result, internal fissures appeared in the film.

The highly hydrophilic nature of the films produced a rather steep drop in E\% when the water activity was increased above 0.6. Thus environments with a high relative humidity should be avoided with this kind of edible film, since the amount of water sorbed increased exponentially in this region.

Another interesting feature was observed for the mechanical properties as the film thickness was varied. As the thickness increased, the TS supported by the film before break increased. An increase in film elongation (E\%) with increasing film thickness was also detected. These increases are related to film crystallinity. As the thickness increased, a longer time for film drying was required and hence a longer time for chain organization became available. Thus, an increase in relative crystallinity was detected with increase in film thickness, which was responsible for the improvement in the mechanical properties.

\section{Acknowledgements}

The authors are grateful for the financial support provided by the Consejo de Investigación de la Universidad Nacional de Salta (CIUNSA) and by the Agencia Nacional de Promoción Científica y Tecnológica (ANPCyT). The authors are also grateful for the technical assistance given by LASEM (Laboratorio de Microscopia Electrónica de Barrido, ANPCyT, CONICET, UNSA) and by the X-Ray Diffraction Laboratory (UNSA).

\section{References}

ARAUJO-FARRO, P. C.; PODADERA, G.; SOBRAL, P. J. A.; MENEGALLI, F. C. Development of films based on quinoa (Chenopodium quinoa, Willdenow) starch. Carbohydrate Polymers, Oxford, v. 81, n. 4, p. 839-848, 2010. http://dx.doi. org/10.1016/j.carbpol.2010.03.051

AMERICAN SOCIETY FOR THE TESTING OF MATERIALS - ASTM. ASTM D882: Standard Test Methods for Tensile Properties of Thin Plastic Sheeting. West Conshohocken: ASTM International, 2010. p. 182-190.

BADER, H. G.; GÖRITZ, D. Investigations on high amylose corn starch films. Part 1: Wide angle X-Ray scattering (WAXS). Starch, Weinheim, v. 46, n. 16, p. 229-232, 1994. http://dx.doi. org/10.1002/star. 19940460606

BertuZZI, M. A.; ARMAdA, M.; GotTifredi J. C. Physicochemical characterization of starch based films. Journal of Food Engineering, Oxford, v. 82, n. 1, p. 17-25, 2007. http:// dx.doi.org/10.1016/j.jfoodeng.2006.12.016

CEREDA, M. P.; HENRIQUE, C. M.; OLIVEIRA, M. A.; FERRAZ, M. V.; VICENTINI, N. M. Characterization of edible films of cassava starch by electron microscopy. Brazilian Journal of Food Technology, Campinas, v. 3, p. 91-95, 2000.

CHANG, Y. P.; CHEAH, P. B.; SEOW, C. G. Plasticizingantiplasticizing effects of water on physical properties of tapioca starch films in the glassy state. Journal of Food Science, Malden, v. 65, n. 3, p. 445-451, 2000. http://dx.doi. org/10.1111/j.1365-2621.2000.tb 16025.x

CHEN, J.; JANE, J. Properties of granular cold-water-soluble starches prepared by alcoholic-alkaline treatments. Cereal Chemistry, St. Paul, v. 71, n. 6, p. 623-626, 1994.

CUNNINGHAM, P.; OGALE, A. A.; DAWSON, P. L.; ACTON, J. C. Tensile properties of soy protein isolate films produced by thermal compactation technique. Journal of Food Science, Malden, v. 65, n. 4, p. 668-671, 2000. http://dx.doi. org/10.1111/j.1365-2621.2000.tb16070.x

CUQ, B.; GONTARD, N.; AYMARD, C.; GUILBERT, S. Relative humidity and temperature effects on mechanical and water vapor barrier properties of myofibrillar protein based films. Polymer gels and Networks, Oxford, v. 5, n. 1, p. 1-15, 1997. http:// dx.doi.org/10.1016/S0966-7822(96)00026-3

CUQ, B.; GONTARD, N.; CUQ, J. L.; GUILBERT, S. Functional properties of myofibrillar protein-based biopackaging as affected by film thickness. Journal of Food Science, Malden, v. 61, n. 3, p. 580-584, 1996. http://dx.doi.org/10.1111/j.1365-2621.1996. tb13163.x

FLORES, S.; FAMÁ, L.; ROJAS, A. M.; GOYANES, S.; GERSCHENSON, L. Physical properties of tapioca-stach edible films: Influence of filmmaking and potassium sorbate. Food 
Mechanical properties of a high amylose content corn starch based film, gelatinized at low temperature BERTUZZI, M. A. et al.

Research International, Oxford, v. 40, p. 257-265, 2007. http:// dx.doi.org/10.1016/j.foodres.2006.02.004

GUILBERT, S.; GONTARD, N.; CUQ, B. Technology and applications of edible protective films. Packaging Technology and Science, Malden, v. 8, n. 6, p. 339-346, 1995. http://dx.doi. org/10.1002/pts.2770080607

JANGCHUD, A.; CHINNAN, M. S. Properties of peanut protein film: Sorption isotherm and plasticizer effect. LTW - Food Science Technology, Oxford, v. 32, n. 2, p. 89-94, 1999. http:// dx.doi.org/10.1006/fstl.1998.0498

JANSSON, A.; THUVANDER, F. Influence of thickness on mechanical properties for starch films. Carbohydrate Polymers, Oxford, v. 56, n. 4, p. 499-503, 2004. http://dx.doi.org/10.1016/j. carbpol.2004.03.019

KOCH, K.; GILLGREN, T.; STADING, M.; ANDERSSON, R. Mechanical and structural properties of solution-cast high amylose maize starch films. International Journal of Biological Macromolecules, Oxford, v. 46, n. 1, p. 13-19, 2010. http:// dx.doi.org/10.1016/j.ijbiomac.2009.10.002

LAZARIDOU, A.; BILIADERIS, C. G. Thermophysical properties of chitosan, chitosan-starch and chitosan-pullulan films near the glass transition. Carbohydrate Polymers, Oxford, v. 48, n. 2, p. 179-190, 2002. http://dx.doi.org/10.1016/S01448617(01)00261-2

LIU, Z.; HAN, J. H. Film-forming characteristics of starches. Journal of Food Science, Malden, v. 70, n. 1, p. E31-36, 2005. http://dx.doi.org/10.1111/j.1365-2621.2005.tb09034.x

LONGARES, A.; MONAHAN, F. J.; O'RIORDAN, E. D.; O'SULLIVAN, M. Physical properties and sensory evaluation of WPI films of varying thickness. LTW - Food Science Technology, Oxford, v. 37, n. 5, p. 545-550, 2004. http://dx.doi.org/10.1016/j. Iwt.2003.12.005

LÓPEZ, O. V.; LECOT, C. J.; ZARITZKY, N. E., GARCÍA M. A. Biodegradable packages development from starch based heat sealable films. Journal of Food Engineering, Oxford, v. 105, n. 2, p. 254-263, 2011. http://dx.doi.org/10.1016/j. jfoodeng.2011.02.029

LOURDIN, D.; COIGNARD, L.; BIZOT, H.; COLONNA, P. Influence of equilibrium relative humidity and plasticizer concentration on the water content and glass transition of starch materials. Polymer, Oxford, v. 38, n. 21, p. 5401-5406, 1997. http://dx.doi. org/10.1016/S0032-3861(97)00082-7

MANGAVEL, C.; BARBOT, J.; BERVAS, E.; LINOSSIER, L.; FEYS, M.; GUÉGUEN, J.; POPINEAU, Y. Influence of prolamin composition on mechanical properties of cast wheat gluten films. Journal of Cereal Science, Oxford, v. 36, n. 2, p. 157-166, 2002. http://dx.doi.org/10.1006/jcrs.2002.0461

MOATES, G. K.; NOEL, T. R.; PARKER, R.; RING, S. G. Dynamic mechanical and dielectric characterization of amylose-glycerol films. Carbohydrate Polymers, Oxford, v. 44, n. 3, p. 247-253, 2001. http://dx.doi.org/10.1016/S01448617(00)00224-1
MYLLÄRINEN, P.; PARTANEN, R.; SEPPÄLÄ, J.; FORSSELL, P. Effect of glycerol on behaviour of amylose and amylopectin films. Carbohydrate Polymers, Oxford, v. 50, n. 4, p. 355-361, 2002. http://dx.doi.org/10.1016/S0144-8617(02)00042-5

PAES, S. S.; YAKIMETS, I.; MITCHELL, J. R. Influence of gelatinization process on functional properties of cassava starch films. Food Hydrocolloids, Oxford, v. 22, n. 5, p. 788-797, 2008. http://dx.doi.org/10.1016/j.foodhyd.2007.03.008

PARK, H. J.; WELLER, P. J.; VERGANO, P. J.; TESTIN, R. F. Permeability and mechanical properties of cellulose-based edible films. Journal of Food Science, Malden, v. 58, n. 6 , p. 1361-1364, 1993. http://dx.doi.org/10.1111/j.1365-2621.1993. tb06183.x

PASCHOALICK, T. M.; GARCÍA, F. T.; SOBRAL, P. J. A.; HABITANTE, A. M. Q. B. Characterization of some functional properties of edible films based on muscle proteins of Nile Tilapia. Food Hydrocolloids, Oxford, v. 17, n. 4, p. 419-427, 2003. http:// dx.doi.org/10.1016/S0268-005X(03)00031-6

RINDLAV-WESTLING, A.; HULLEMAN, S. H. D.; GATENHOLM, P. Formation of starch films with varing crystallinity. Carbohydrate Polymers, Oxford, v. 34, n. 1-2, p. 25-30, 1997. http://dx.doi. org/10.1016/S0144-8617(97)00093-3

RINDLAV-WESTLING, A.; STADING, M.; HERMANSSON, A.M.; GATENHOLM, P. Structure, mechanical and barrier properties of amylose and amylopectin films. Carbohydrate Polymers, Oxford, v. 36, n. 2-3, p. 217-224, 1998. http://dx.doi.org/10.1016/ S0144-8617(98)00025-3

RYU, S. Y.; RHIM, J. W.; ROH, H. J.; KIM, S. S. Preparation and physical properties of zein-coated high-amylose corn starch film. LTW - Food Science Technology, Oxford, v. 35, n. 8, p. 680-686, 2002. http://dx.doi.org/10.1006/fstl.2002.0929

SOBRAL, P. J. D. Influência da espessura de biofilmes feitos a base de proteínas miofibrilares sobre suas propiedades funcionais. Pesquisa Agropecuária Brasileira, Brasília, v. 35, n. 6, p. 1251-1259, 2000. http://dx.doi.org/10.1590/S0100204X2000000600022

VAN SOEST, J. J. G.; HULLEMAN, S. H. D.; DE WIT, D.; VLIEGENTHART, J. F. G. Change in the mechanical properties of thermoplastic potato starch in relation with changes in B-type crystallinity. Carbohydrate Polymers, Oxford, v. 29, n. 3, p. 225-232, 1996. http://dx.doi.org/10.1016/01448617(96)00011-2

VAN SOEST, J. J. G.; VLIEGENTHART, J. F. G. Crystallinity in starch plastics: consequences for material properties. Trends in Biotechnology, Oxford, v. 15, n. 6, p. 208-213, 1997. http:// dx.doi.org/10.1016/S0167-7799(97)01021-4

ZHANG, Y.; HAN, J. H. Plasticization of pea starch films with monosaccharides and polyols. Journal of Food Science, Malden, v. 71, n. 6, p. E253-261, 2006. http://dx.doi.org/10.1111/ j.1750-3841.2006.00075.x 